\title{
THE MEDICAL AND ECONOMIC FATE OF TWENTY-NINE INDUSTRIAL SPINAL CORD INJURED PATIENTS
}

\author{
By S. J. Peerless, M.D., F.R.C.S.(C)., and J. F. Schweigel, M.D., F.R.C.S.(C) \\ Division of Neurosurgery and Division of Orthopaedics, University of British Columbia, \\ Vancouver, B.C., Canada
}

A DETAILED analysis of 29 spinal cord industrial injured patients has been made. The mechanism of injury, types of treatment, complications and economic costs have been studied. Other groups of such patients have been studied in the past, but often the economic cost has not been presented in detail.

\section{MATERIAL}

Twenty-nine industrial injured paraplegics and tetraplegics have been treated in the Province of British Columbia from 1957 to 1963 . They were all young males with an average age at the time of injury of $36 \cdot 5$ years. Two-thirds of the cases were married at the time of injury. The occupations reflect the type of industries peculiar to British Columbia (Table I).

In the industrial spinal cord injured patient the pathogenic factor causing the injury is major trauma and is not due to factors intrinsic to the spinal cord itself, such as tumour pathology, etc. (Table II).

Two-thirds of the cases were paraplegic and one-third were tetraplegic. The pathological anatomy consisted of fractures in I4 cases, fracture dislocations in another I4 cases, and a central cord syndrome with no associated fractures or dislocations in one case. The anatomical level of injury is seen in Table III.

The severity of trauma often produces associated injuries. Sixteen cases ( 55 per cent) had fractures in sites other than the spine. Twenty-four of the 29 cases had some form of early spine surgery (Table IV). Eighteen of these 24 cases, namely 75 per cent, had surgery to the spine within one month of injury and the remaining six cases had surgery to the spine within eight months of injury.

All 29 cases had one or more surgical procedures performed on them sometime after the onset of the spinal injury (Table V).

Fifteen cases had some form of orthotic device to the lower extremity. Four were below knee braces, seven above knee and four were body braces.

Nine of these 29 cases were said to have some form of ambulation. Only three of these nine lesions were proximal to the $\mathrm{L}_{3}$ level (Table VI). It should be stated that ambulation was a vague term and often meant putting braces on and walking only a few feet.

There were II 3 complications occurring in these 29 cases for an average incidence of four complications per patient (Table VII). The pressure sores developed within a few days of onset of injury to within a few months from onset of injury in 50 per cent of cases (Table VIII). One case died within three years after injury secondary to multiple complications and personal neglect. This patient had recurrent bleeding from within and multiple infected pressure sores.

The cost to manage the 29 cases were divided into two parts. The first part was the sum of money set aside as lost earnings for each patient and was related 


\section{TABLE I}

Occupation of the 29 industrial spinal cord injured patients in British Columbia

$\begin{array}{lc}\text { Logger } & \text { I3 }(45 \%) \\ \text { Truck driver } & 4 \\ \text { Miner } & 2 \\ \text { Miscellaneous } & \text { I0 } \\ & 29 \\ \text { Total } & 29\end{array}$

TABLE II

Cause of injury to the industrial spinal cord injured patient

$\begin{array}{lr}\text { Fall from a height } & 7 \\ \text { Struck by a tree } & \text { II } \\ \text { Struck by a car } & 8 \\ \text { Miscellaneous } & 3 \\ & \frac{29}{}\end{array}$

\section{TABLE III}

The anatomical level of spinal cord injury

$\begin{array}{lr}\text { Cervical } & 5(\mathrm{I} 7 \%) \\ \text { Thoracic } & \mathrm{I} 6(55 \%) \\ \text { Lumbar } & 8(28 \%)\end{array}$

TABLE IV

Type of early surgery to the spine

$\begin{array}{lr}\text { Laminectomy } & \text { II }(38 \%) \\ \text { Laminectomy and fusion } & 8(28 \%) \\ \text { Fusion } & 5(17 \%) \\ & -24\end{array}$

\section{TABLE V}

Other operative procedures on the spinal cord injured patient

Neurosurgical and orthopaedic procedures

$\begin{array}{rc}\text { Cases } & \text { Procedures } \\ \text { I5 } & \text { 2I } \\ 4 & 7 \\ 4 & \text { I7 } \\ \text { I5 } & 3 \text { I } \\ \text { 2I } & 84 \\ 2 & 2 \\ 2 & 6 \\ \text { II } & \text { II } \\ 2 & 2\end{array}$

eneral surgery

Plastic surgery

Urological surgery

Cystostomy

Ileo-loop bladder

Dilatation of the urethra

Other G.U. surgery

Miscellaneous surgery

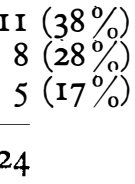




\section{TABLE VI}

Site of lesion in ambulatory patients

Site of lesion

Cervical central cord lesion

Tiz lesion

L3 lesion

L4 lesion

L5 lesion

Total
Number of cases

\begin{tabular}{l} 
I \\
2 \\
2 \\
2 \\
2 \\
\hline 9
\end{tabular}

9

\section{TABLE VII}

Early and late complications in 29 spinal cord injured patients

A. General complications:

$\begin{array}{cc}\text { Number } & \begin{array}{c}\text { Total number } \\ \text { of cases }\end{array}\end{array}$

Burns

Pressure sores

2

Dermatitis

33

Phlebitis

Pulmonary embolus

Delayed wound healing

Miscellaneous

B. Musculoskeletal complications:

$\begin{array}{rr}2 & 2 \\ 17 & 33 \\ 2 & 2 \\ 3 & 3 \\ 1 & 1 \\ 3 & 3 \\ 5 & 6\end{array}$

\section{Fractures}

Myositis ossificans

Kyphosis

Contractures

C. Urological complications:

Hydronephrosis .

Kidney or bladder infection

Urethral fistula

Calculi

Epididymitis

Urethral diverticulum

Hydrocele

D. Psychiatric cases:

Total

\begin{tabular}{rr}
7 & 7 \\
$\mathrm{I}$ & $\mathrm{I}$ \\
3 & 3 \\
3 & 3 \\
8 & 8 \\
6 & 6 \\
4 & 4 \\
$\mathrm{I} 2$ & $\mathrm{I}$ \\
6 & 6 \\
2 & 2 \\
$\mathrm{I}$ & $\mathrm{I}$ \\
4 & 4 \\
\hline- & - \\
90 & $\mathrm{IIO}$
\end{tabular}

TABLE VIII

Onset of pressure sores

Number of cases

Time af ter injury

I day

4 days

2 months

3 months

6 months

I I

Greater than 6 months 
to the monthly earnings the patient received at the time of injury multiplied by his life-expectancy years. These 29 cases had an average of $\$ 64,000$ set aside for them which represented their salary over their life expectancy for a total of approximately $\$ 2,000,000$. The second part of the cost was the amount of money that has been spent over the years to maintain health in these 29 patients (Table IX). For the life expectancy of these 29 spinal cord injured patients, about $\$ 2,000,000$ will be spent to maintain satisfactory health. The major expenses will be: hospitalisation (63 per cent); nursing care ( 18 per cent); medical care (6.6 per cent); and surgical supplies (6.5 per cent).

TABLE IX

Distribution of money to maintain health in 29 spinal cord injury patients from 1957 to 1969

$\begin{array}{lrcc}\text { Distribution to } & \begin{array}{c}\text { Amount } \\ \text { in dollars }\end{array} & \begin{array}{c}\text { Percentage } \\ \text { of total }\end{array} & \begin{array}{c}\text { Cost per patient } \\ \text { per year in dollars }\end{array} \\ \text { Hospitals } & 43 \mathrm{I}, 873 & 63.00 & \mathrm{I}, 587.77 \\ \text { Nursing care } & \mathrm{I} 23,756 & \mathrm{I} 8.06 & 455.00 \\ \text { Doctors } & 45,023 & 6.57 & \mathrm{I} 65.53 \\ \text { Surgical supplies } & 44,7 \mathrm{I2} & 6.52 & \mathrm{1} 64.38 \\ \text { Druggist } & 22,553 & 3.29 & 82.92 \\ \text { Transportation } & \mathrm{I} 4,922 & 2.18 & 54.86 \\ \text { X-ray } & \mathrm{I}, 674 & 0.24 & 6.15 \\ \text { Physiotherapy } & 370 & 0.05 & \mathrm{I} .36 \\ \text { Subsistence } & 293 & 0.04 & \mathrm{I} .08 \\ \text { Dental } & \mathrm{I} 59 & 0.02 & 0.58 \\ & -\ldots- & --.00 & - \\ \text { Total } & 685,335 & \text { I00.00 } & 2,519.63\end{array}$

\section{DISCUSSION}

The incidence of spinal cord injured patients in the world is variable, but is reported to be 12 to 15 new patients per year per million of population in western countries (Lougheed et al., I970).

A recent study (Peerless \& Schweigel, I97I) has shown that the present facilities and philosophy of management needlessly prolongs the initial hospitalisation of the individual with a spinal injury and in many instances the final level of social and occupational rehabilitation is insufficient to permit the patient to return to a useful role in society. Symington wrote (Symington \& Fordyce, I965): 'It is sometimes said that patients with spinal injuries are too sick to be moved to major centres. Actually they are too sick to be safely managed in smaller hospitals.'

As such, it is proposed that an acute spinal cord injury unit would ensure maximum recovery of such patients. Most acute spinal cord injury units attempt to admit such patients as early as possible after injury (Guttmann, 1963). Key and Retief (1970) admits 72 per cent of such patients within 48 hours of injury. If the patient is within 200 miles of his unit, he is transported by ambulance, and if greater than this distance, by chartered airplane accompanied by a physiotherapist. Other authors (Chesire, I969) also attempt to admit such patients as early as possible after injury.

Over 82 per cent of spinal cord injured patients are secondary to trauma, and the remainder are associated with other pathology (Lougheed et al., 1970). Because 
trauma plays such a major role in the pathogenesis of this problem, the patients are often very young, as seen in this study and others (Lougheed et al., 1970). The ratio of paraplegics to quadraplegics is usually $2:$ I (Key \& Retief, I970; Lougheed et al., I970).

The question of whether early or late surgery to the spinal column is necessary, is difficult to answer. Most cases within this study had early laminectomy and fusion, but it is difficult to say whether the patient improved after surgery. The Stoke Mandeville Hospital (Frankel et al., 1969) reported on only four unstable spines in 600 fractured spines after 12 weeks of non-operative treatment. Chesire (Chesire, I969) had I 2 patients with instability of the spine I 2 weeks after spinal fracture out of $2 \mathrm{I} 2$ spinal cord injuries.

The complication rate increases proportionally to the delay of admission to an acute spinal centre. Cibeira (1970) in analysing 365 paraplegics admitted to his centre, found that only 13 per cent were admitted within one month of injury and 65 per cent of this total had pressure sores and Ioo per cent had urinary tract infections. Proper staffing and apparatus such as the Egerton-Stoke Mandeville Turning Bed (Guttmann, I965, I967; Frankel et al., 1969) or the Roto-Rest Bed (Keane, 1970), can decrease the incidence of bed sores to zero and can secondarily decrease the cost of patient's care. (The cost of the bed is only one-half the cost of caring for one bed sore.)

The cost of maintaining the health in the spinal cord injured is primarily due to hospital costs (63 per cent) as seen in Table IX. By decreasing complications, hospital stay is decreased and so is the cost of patient care. Rancho Los Amigos Hospital (Personal Communication) has been able to discharge most of their patients within three to four months of admission. These patients are discharged fully rehabilitated and are, as such, suitable for job training.

Proper facilities are mandatory to decrease the incidence of renal complications. Jousse et al. (I968) showed that the commonest cause of death in paraplegics is renal failure ( 36 per cent). Guttmann and Frankel (I966) are the proponents of intermittent catheterisation. Dollfus \& Mole (1969) used Guttmann's technique and found that of 16 patients admitted within 24 hours of injury, more than 80 per cent had sterile urines three months later.

TABLE X

Ratio of staff to patients for a 25-bed spinal cord injury unit

Number of nurses and aides

Physiotherapist and Occupational Therapist

Rancho Los

Physician

Psychologist

Social Worker

$\begin{array}{crr}\text { Amigos Hospital } & \text { Bors } & \text { Key } \\ 25 & 23 & \text { I } \\ 5 & 2 & 4 \\ -- & \text { I:20 } & - \\ -- & 1: 40 & -- \\ -- & 3: 40 & -- \\ & 28 \frac{1}{2} & \end{array}$

The ratio of staff to patients varies from unit to unit. Bors (1967), Key and Retief (1970), and Rancho Los Amigos Hospital (Personal Communication) give estimates on this ratio (Table $\mathrm{X}$ ). These figures vary depending on what ancillary beds, et cetera, are available. 


\section{SUMMARY}

The care of the spinal cord injured patient has improved since the Second World War. This is especially true where acute spinal injury centres exist. In such centres, the general care of the patient is emphasised to enable the patient to return to society with maximum return of function. This study supports the concept of such an acute spinal cord injury unit.

\section{RÉSUMÉ}

Le traitement des malades avec une atteinte médullaire s'est amélioré depuis la deuxième guerre mondiale. Ceci est surtout vrai là où existent des Centres Spécialisés. Dans ces Centres, le but principal est de permettre au malade de retourner dans la société avec un retour maximum des fonctions. Cette étude supporte l'idée de l'éstablissement d'un tel Centre.

\section{ZUSAMMENFASSUNG}

Die Fürsorge des spinal Verletzten hat seit dem 2. Weltkrieg Fortschritte gemacht, insbesonder wo akute Spinale Zentren existieren. In diesen Zentren wird die Allgemeinfürsorge betont, um den Patienten zur Gemeinschaft mit dem Maximum von Funktion zurückzukehren. Diese Studie unterstützt die Konception der akuten Spinalzentren.

\section{REFERENCES}

Bors, E. (1967). The Spinal Cord Injury Centre of the Veterans Administration Hospital, Long Beach, California, U.S.A. Facts and thoughts. Paraplegia, 5, 126-130.

ChEsIRE, D. J. E. (I969). The stability of the cervical spine following conservative treatment of fractures and fracture-dislocations. Paraplegia, 7, 193-203.

Cibeira, J. B. (1970). Some conclusions on a study of 365 patients with spinal cord lesions. Paraplegia, 7, 249-254.

Dollfus, P. \& Mole, L. (1969). The treatment of the paralysed bladder after spinal injury in the accident unit of Colmar. Paraplegia, 7, 204-205.

Frankel, H. L., HANCOCK, D. O., HYSLOP, G. et al. (I969). The value of postural reduction in the initial management of closed injuries of the spine with paraplegia and tetraplegia, I. Paraplegia, 7, 179-192.

Guttmann, L. (1963). Spinal cord injuries. In Sympos. Roy. Coll. Surgeons, Edinburgh, pp. 80.

GutTMANN, L. (1965). A new turning-tilting bed. Paraplegia, 3, I94.

GuttmanN, L. (1967). New turning-tilting bed and Head-traction Unit. Brit. med. $\mathcal{F}$. I, 288 .

Guttmann, L. \& Frankel, H. (1966). The value of intermittent Catherterisation in the early management of traumatic paraplegia and tetraplegia. Paraplegia, 4, 63-68.

Jousse, A. T., Synne-Jones, M. \& BReithaupt, D. J. (I968). A follow-up study of life expectancy and mortality in traumatic transverse myelitis. Can. Med. Ass. F. 98, 770-772 (20 April).

Keane, F. (I970). Roto-rest. Paraplegia, 71, 254-258.

Key, A. G. \& Retief, P. J. (I970). Spinal cord injuries. An analysis of 300 new lesions. Paraplegia, 7, 243-249.

Lougheed, W. M., Bertrand, D. \& Hay, R. (I970). Paraplegic Care in Canada I969: A report of a subcommittee of the Canadian Neurosurgical Society June 1969. Modern Med. 25, I7-24 (March).

PeErless, S. J. \& Schweigel, J. F. (I97I). A proposal for a spinal cord injury unit at Shaughnessy Hospital. C.P.A. Preliminary Research Review.

Symington, D. C. \& FoRDYCE, W. E. (I965). Changing concepts in the management of traumatic paraplegia. GP, 32, I40-55 (September).

Second Annual Progress Report of the Spinal Cord Injury Rehabilitation Centre. Rancho Los Amigos Hospital, Downey, California, U.S.A. Personal Communication. 